The Political Economy of Development in India Since Independence

Stuart Corbridge

Development Studies Institute

London School of Economics

Forthcoming, 2009: in Paul Brass (ed). Handbook of South Asian Politics London: Routledge 


\section{The Political Economy of Development in India Since Independence}

\section{Introduction}

India has been acclaimed in recent years as an information technology (IT) superpower and perhaps even as a major new player in the world economy. The Indian economy has been growing at around 5 or $6 \%$ per annum since 2003, adjusted for population growth, and there are good reasons to suppose that similar rates of growth of gross domestic product (GDP) per capita might be sustainable over the next twenty years. Savings rates are very high in India. Indeed, at just over 30\% of GDP, gross domestic savings are approaching East Asian levels. The economy sits well inside its total factor productivity frontier, in large part because of low levels of human capital formation, and the country now has the chance to reap a demographic dividend: the ratio of dependents to workers is set to decline from just over 0.6 in 2000 to just under 0.5 in $2025 .{ }^{1}$ The launch in J anuary 2008 of the Tata Nano seemed like icing on this cake of economic success. Much was made in the West about a car selling for $\$ 2,500$, but in India the marketing of a car for one lakh $(100,000)$ rupees spoke to the existence of a mass middle class. It also signalled the rise of a small group of Indian capitalists and entrepreneurs who could bestride the global stage. Four-lane highways packed with Nanos offered a vision of India far removed from one of pot-holed roads shared by bullock carts, scooters and state-built Ambassador cars. In the words of Gurcharan Das, India had been unbound. ${ }^{2}$ It had escaped from a Kafkaesque world of bureaucratic red-tape to take its place in the global information age.

Now, there are clearly nuggets of truth in accounts of India's political economy that hinge around 1991, as Das's book largely does. Yet the notion that all was bad or sick before "the reforms" or that all has been good or healthy since, fails to provide a nuanced picture of economic development in India since Independence. Recent academic work 
points out that high rates of economic growth are now being achieved in India in part because of past legacies, some more intended than others, and not wholly in spite of them. Investments in higher education and basic industries are two cases in point. ${ }^{3}$ Recent work also points out that economic reform did not begin overnight in 1991, but was prefigured in important respects by the pro-business agendas pursued by Prime Ministers Indira Gandhi and Rajiv Gandhi in the 1980s. In any case, the real turning point in India's trend rate of economic growth was 1980-81, not the early-1990s, although there are signs that the trend rate has improved again since 2003-04. ${ }^{4}$

We also need to acknowledge that post-reform growth in India has reduced absolute poverty less quickly than might have been expected, particularly through the 1990s. The incidence of absolute poverty is much less now than it was at the end of the 1970s, when something like $50 \%$ of Indians were poor, but a Tata Nano driven from Delhi to Kolkata still takes its riders through the epicenter of world poverty. The Government of India (GOI) uses a particularly brutal measure of absolute poverty, one that is more basic even than the "one dollar a day" definition used by the leading multilateral institutions. Yet even on this measure some 250 million people in India are finding it hard to keep body and soul together-fewer than 100 million people less, in total numbers, from the figure of 350 million in 1980. As many as 750 million people survive on less than two dollars a day.

Social and spatial inequalities have also increased sharply since 1990. Rising inequality levels are inevitable in a country escaping a low-level equilibrium trap, a point made by Simon Kuznets many decades ago. ${ }^{5}$ We can refer to "good inequality" where it is based on higher rewards to talent and entrepreneurship. But there is also "bad inequality," and this occurs when people are locked out of markets, or from the schools, roads and other routes that lead to the acquisition of human capital and other transferable skills, perhaps on the basis of gender or caste or ethnicity. What is worrying about recent developments in India is the abundance of bad inequality and unemployment. Governments continue to invest meagerly in the provision of public goods, particularly in 
the eastern part of the country. Naxalism is one index of pervasive government failure in a group of states running south from Bihar to Andhra Pradesh. For rural people in these states, as the World Bank has recently reminded us, living standards are about on a par with living standards in rural areas of sub-Saharan Africa. ${ }^{6}$ They are a long way removed from the living standards of India's urban middle classes. In contrast, as the World Bank also points out, the richer parts of New Delhi, Mumbai and Bangalore can reasonably be described as India's “Latin Americas.”

These inequalities are holding back economic and social development in postreform India. They led J ohn Harriss and me to conclude that economic reform in India in the 1990s had taken the form of an "elite revolt" against those aspects of the dirigiste state that most constrained a loose coalition of business groups and the urban middle classes. ${ }^{7}$

That revolt has wrought some important and much needed changes in India's economy. It has also helped to re-work key political relations between the central state and the provinces and between the state and its citizens. But the reform process remains highly uneven, both in its mainsprings and in its consequences. I shall argue here that the term "elite revolt" still works well as a descriptor of the contradictory dynamics of political and economic change in India over the past two decades.

\section{The Political Economy of Growth in India, 1950-1980}

When the British quit India in 1947 they left behind an economy scarred by two centuries of policies that aimed to put the empire first. It is true that the British invested heavily in a railway system that linked most of the major towns and cities in South Asia. They also sank considerable sums of money into the canal colonies of Punjab and provided new systems of property rights and commercial law in both rural and urban areas. The British could even maintain in 1947 that they had built India into the world's tenth largest industrial power. There were large textile industries in Ahmedabad and Bombay, and an 
iron and steel industry in Bihar and Orissa (thanks mainly to J amsetji Tata). But what this rosy picture neglects is the involution of the countryside in Bengal that followed the Permanent Settlement of 1793—a settlement that promoted rack-renting landlordism rather than capitalist farming - and the undermining of many of India's craft industries as imports flooded in from Lancashire and elsewhere. The grim truth of British misrule was apparent in a series of famines that hit India at the end of the nineteenth century, and which culminated in the deaths of three million people in Bengal in 1943-44. Alan Heston has estimated that average living standards in the Indian countryside barely improved from 1900 to 1947.8 There were always significant regional variations within this general picture, but it is likely that as many as two in three Indians lived in absolute poverty at the mid-point of the twentieth century.

Against this backdrop, and given the loss in 1947 of the jute economy of east Bengal (first East Pakistan, now Bangladesh), as well as the loss of the major port city of Karachi, it is not surprising that India's first plans for economic development took shape in an atmosphere of crisis. The First Five Year Plan (1951-56) was something of a damp squib and remained broadly neutral as between the agricultural and non-agricultural sectors. After the assassination of Mahatma Gandhi in J anuary 1948, the remaining "tall men" of India's nationalist elite were forced to occupy themselves mainly with nation-building in a broader sense, with Sardar Patel working hard to ensure the de facto integration of India's 565 Princely States into the new Republic, while B R Ambedkar and J awaharlal Nehru oversaw work on the Constitution. It was clear by 1950 that India would be a federal democratic republic in which universal suffrage would be coupled to the establishment of a central state with considerable executive and emergency powers and matching geographical reach. Ambedkar and Nehru agreed that the social and economic modernization of India would have to be secured by vigorous planned actions emanating from New Delhi. Conservative politicians sitting in the states would be disciplined by wiser and more far-sighted men sitting in the country's capital. Modernization was conceived as 
a diffusion process wherein great pulses of social and economic change-ultimately liberating and uplifting, if often disruptive of established ways of life in the short-runwould push outwards from India's major cities to its smallest towns before reaching into the countryside. ${ }^{9}$

Ambedkar would later break with Nehru over the failure of his government to transfer surplus lands specifically to so-called untouchable (or Dalit) families. Ambedkar had warned at the end of the Constituent Assembly debates that India was about "to enter a life of contradictions. In politics we will have equality and in social and economic life we will have inequality." In his view, the failure to redistribute landed wealth in India would put "our democracy in peril."10 It seems likely that Nehru shared this view, although he had more faith than Ambedkar in the economically empowering effects of political "equality." In any case, by 1951 Nehru was unchallenged in his leadership of the Indian National Congress. His ascendancy followed the death of Patel in December 1950 and the defeat of Patel's close supporter, Purushottam Das Tandon, in a struggle for the presidency of the Indian National Congress. But Nehru still had to secure consent for his project of social and economic modernization, and this meant that he had to deal with precisely those state Congress bosses who would conspire against his plans for land-to-the-tiller land reforms in the 1950s. ${ }^{11}$

Nehru sought to manage the modernization of India by pursuing a development model that was being widely touted by economists even as the Second Five Year Plan was drafted. Early development economics took shape in the 1940s and 1950s around three key ideas. First, there was a critique of comparative advantage theory. Hans Singer and Raoul Prebisch took issue with the idea that latecomer countries could develop effectively as primary goods producers. ${ }^{12}$ There were both theoretical and empirical reasons to suppose that prices of non-primary goods rose faster over time than the prices of primary commodities. Developing countries had to build up local (infant) industries as a priority, even if this meant erecting tariff barriers to protect the domestic economy. ${ }^{13}$ Second, this 
commitment to import-substitution industrialization (ISI) implied in the short term a run of balance of trade deficits. Developing countries first had to import the machine tools and other goods that would help them build up local manufacturing capacity. A foreign exchange constraint would become especially compelling in a country like India where ISI privileged the production of capital goods (iron and steel, chemicals, heavy engineering, etc). Flows of foreign direct investment were thin on the ground in the 1950s and 1960s, and probably would not have been very welcome in India. A surplus on the capital account would thus have to be achieved by large and continuing inflows of foreign aid. Nehru's ability to position India at the head of the Non-Aligned Movement helped in this respect. India was able to build a steel mill at Bokaro (Bihar) with assistance from the USSR and another at Rourkela (Orissa) with help from West Germany. Third, the very scarcity of foreign exchange in the 1950s and 1960s, coupled with poorly formed local stock markets and often weak private trading systems (some of which were coded as "oppressive" or exploitative), inclined the Government of India (GOI) to think of economic development as a project that had to be planned for and delivered by a beneficent state. Ronald Inden exaggerates only a little when he says that in the Nehru-Mahalonobis universe planning came to substitute for religion as the new Godhead. ${ }^{14}$ Nehru's faith in Reason and Modernity complemented a more general mid-century faith in technology and progress, both of which needed support from Good (or at any rate Strong) Government.

Thus conceived, India's model of development through most of the 1950s and 1960s made a virtue of deferred gratification. Nehru and Mahalanobis believed that high rates of economic growth would depend on high rates of personal and government savings (equivalent to present consumption foregone), and their efficient mobilization for purposes of large-scale industrialization. By definition, this first wave of capital-goods based production would not be labor intensive; it would not create large numbers of goods for the under-employed peasants who wanted to leave the countryside to find more productive jobs in the modern sector. This Lewisian transformation would have to await 
the second stage of India's industrial revolution. ${ }^{15}$ Cheap steel, chemicals and power could then be plugged into a plethora of efficient Indian-run companies that would produce bikes, radios, two-wheel tractors and such-like for the final consumer.

Put another way, the Nehru-Mahalanobis model presupposed that India would be governed by a developmental state of the type that would soon take shape in East or SouthEast Asia. This would be a state that was relatively autonomous of privileged local classes, as Marxist theoreticians liked to put it. In India, it would be embodied in the Planning Commission and the Five Year Plans. The state would specify a social welfare function for the future $(5,10,15$ or 25 years away) and then devise the best economic and statistical instruments to match inputs to outputs. The model further supposed that the GOI could funnel resources from the agricultural sector to the non-agricultural sector without provoking a backlash among India's rural population. Nehru believed that he could square this circle in two main ways: firstly, by making use of food aid from the USA, and secondly by means of land ceilings legislation that would break up unproductive estates and enfranchise efficient small farmers. India's countryside would be bought off not with state funds, but with resources from abroad and by institutional reform at home. Agriculture was the "bargain basement" that would free up scarce resources for use elsewhere in the developing economy. ${ }^{16}$ Except it did not, or not as Nehru had hoped.

By the early-1960s it was apparent that increases in grain production were barely keeping pace with population growth. Food supply growth in the 1950s came mainly from increases in the area under cultivation, and now the land frontier was closing. By the mid1960s many farmers were bemoaning their lot. The great J at farmers' leader, Charan Singh, had opposed Nehru's plans for cooperative farming in the 1950s. In 1967, he defected from the Congress, before setting up the Bharatiya Kranti Dal in 1969. Charan Singh, in his extensive writings on agriculture and agricultural policy in India, anticipated Michael Lipton's later claim that India was suffering from high levels of urban bias. ${ }^{17}$ Government spending decisions were denounced as inequitable, inefficient and 
unsustainable. In a country where more than $75 \%$ of the people still lived in the countryside-agriculture's share of GDP was as high as 58\% in 1950, and not much less than 50\% in the mid-1960s-it made little sense to waste capital on inefficient urban and industrial projects. The need instead was to fund new irrigation systems and off-farm employment growth in the countryside.

This view gained currency at the end of the 1960s, following the failures of the 1965 and 1966 monsoons, and in the wake of new data showing that the incidence of absolute poverty in the Indian countryside had increased from 1961 to 1969.18 Nehru died before the crisis of India's agriculture was fully exposed and before the suspension of planning in 1966-69. But his death also came after a disastrous war with China in 1962, and these events taken in the round would continue to infect the poisonous political and economic atmospheres in which first Lal Bahadur Shastri (1964-66) and then Indira Gandhi had to make their way as prime ministers.

Indira Gandhi has many times been compared unfavourably with her father (Nehru), and very often for good reason. She deserves to be condemned above all for the disastrous way that she fought religious fire with fire in Punjab in the early 1980s, when she covertly supported Sant J arnail Singh Bhindranwale, and for her government's suspension of democratic rule in India during the Emergency (1975-77). But what is sometimes forgotten in these comparisons is that Mrs. Gandhi came to power at a time when India's democracy was deepening, when the dominance of the Congress System was for the first time being challenged in New Delhi and the states, and when state-society relations more generally, in the words of Lloyd and Susanne Rudolph, had moved from a pattern of "command politics" to one of "demand politics."19 The new political landscape of the 1970s and 1980s saw not only the deinstitutionalization of the Congress and the rise of credible opposition parties; it also marked a period in India's political economy when a prospectively developmental state imploded. ${ }^{20}$ That state had always been an uneasy construct in India, as Partha Chatterjee and Sudipta Kaviraj have several times reminded 
us. ${ }^{21}$ Nehru mobilized large sections of the English-speaking "progressive" elite in support of his modernizing agenda. But this elite was fated to see its ambitions translated at local level by power brokers who rarely shared its commitments to the "greater good" or the "long run." Local worlds were more often vernacular worlds, or worlds where commitments were most often forged at the level of a household, kin group or caste community. As Kaviraj so memorably puts it, India's high modernist state "had feet of vernacular clay."22

Worse, the developmental state model presupposes an executive state that is autonomous from a country's dominant proprietary elites. Such was the case, for example, in Taiwan, where the ruling elite after 1949 was transplanted from mainland China, and was later funded by the USA as well as by rental incomes from land. "Land to the tiller" land reform worked in Taiwan, just as it did in South Korea in the 1950s. Regime changes ensured that a developmental state was not confronted by entrenched powers elsewhere in the land. In India, in contrast, as scholars as diverse as Francine Frankel, Pranab Bardhan and J agdish Bhagwati have all shown, the developmental state was captured by three interlocking groups: India's richer farmers (who blocked agrarian reform), its industrial bourgeoisie (business houses that took advantage of state-induced scarcities and which blocked competition and innovation), and the country's leading bureaucrats (many of whom earned large rental incomes from the "Permit-License-Quota-Raj” built up around ISI, and almost all of whom enforced unproductive rent-seeking behaviour on smaller businesses and ordinary citizens).23

The so-called "Hindu rate of growth" that dogged India in the 1970s reflected the squeeze placed on the country's developmental state by aggressively sectional interests. The state was now forced to accommodate to the demands of these interest groups, no matter whether they acted for the greater good. Average GDP growth in the 1970s was 2.9\% per annum, which was barely positive in per capita income terms. In some accounts, too, the greater costs of participating in India's competitive politics led some politicians to 
finance their campaigns illegally and/ or through abuses of office. Civil servants, for example, were forced to stump up greater rents to acquire a desirable posting, or to head off an undesirable one. Criminals, for their part, moved into politics, both to milk the system and to ward off unwelcome attention from the justice system. The criminalization of politics became particularly marked in parts of north India from the 1970s and posed yet another barrier to economic reform there.

Lobbying, of course, is endemic to all political systems, and what is called lobbying in Washington or London is all too routinely described as corruption in New Delhi or Dhaka. Corruption also comes in many forms, and when it takes the form of speed money payments it can grease the wheels of an economic system that otherwise tends to atrophy or entropy. And it is at this systemic level, as economic reformers like Bhagwati and Srinivasan have pointed out, that the bigger picture lies. ${ }^{24}$ The failure of the Congress Party in the 1950s and 1960s to support an executive/ developmental state left India's economy between two stools. On the one hand, the state was not strong enough to force the commanding heights of the economy to be lean and mean, let alone to dispense with the subsidies and protectionist barriers that were meant to provide them with temporary support. Neither management nor organized labor believed that governments in the 1970s or 1980s had the guts to get tough with them. On the other hand, the central role occupied by the state in India's productive economy—from steel to cars to banking—was so great that it suffocated innovation and new start-ups in the organized private sector. Even into the mid-1980s, India's leading industrial houses were happy to connive in the reproduction of this world of the second- or third-best. For that to change, or so this argument goes, the contradictions of dirigiste development in India would necessarily come to a head, as they did with the fiscal and balance of payments crises of the early1990s. Only then would politicians and leading business people in India be forced to reform the economy and to reform the political systems that had supported economic mismanagement on a grand scale. 


\section{The Political Economy of Reform in India}

As ever, it is not difficult to recognize the truth of some of these claims. But what this narrative of rise, decline and recovery cannot account for is the upturn in India's rate of economic growth post-1980. The fact is that per capita incomes in India grew on average at $3.8 \%$ in the $1980 \mathrm{~s}$, or at more or less the same rate as they grew in the 1990s. There are three main reasons why this was so. To begin with, as Atul Kohli has argued, the governments of Indira Gandhi and Rajiv Gandhi (1980-89) began to tilt economic policy more clearly in the direction of big business. ${ }^{25}$ The courting of foreign direct investment was still not a priority through the 1980s, although a few joint ventures were brokered in the autos sector. Nevertheless, the strongly anti-capital (especially, anti-foreign capital) rhetoric that Indira Gandhi had deployed in the 1970s was toned down. Newinitiatives were introduced that favored established Indian producers. In place of garibi hatao (end poverty), the political platform on which Indira Gandhi made her name in the early 1970s, the Congress governments of the 1980s retired those parts of the Monopolies and Trade Practices Act which made it hard for big business to expand in core sectors like chemicals and cement. Some efforts were also made to liberalize credit for large companies. Perhaps most importantly, both Indira and Rajiv Gandhi took steps to tame labor activism in the organized sector, and to encourage private sector investments with limited tax concessions.

Kohli argues that a major effect of these policy changes was to shift the balance of capital formation in India through the 1980s. Albeit at the margin, it was the private corporate sector that now began to contribute more to economic development, while capital formation in the public sector stabilized after a period of rapid growth in the 1970s. It seems likely, too, that the growth-inducing effects of a pro-business tilt were augmented by the gradual diffusion of Green Revolution technologies out of Punjab, Haryana and parts of south India. West Bengal now became a Green Revolution heartland, following significant government investment in irrigation and electricity supply. 
Poor people in the countryside generally escape from poverty by migrating to towns or cities, or by winning more work in the countryside at higher real wage rates. There is some evidence that labor markets tightened in the 1980s in several states, including West Bengal, Andhra Pradesh and Karnataka. By 1989-90, the percentage of people in India living in absolute income poverty had reduced to just under 39\% from 51\% in 1977-78. The GOI in the early-2000s liked to claim that the rate of poverty reduction accelerated again after the reforms of 1991. Most scholars, however, have discounted the suggestion of the 55th round of the National Sample Survey (NSS) that just 26\% of people were absolutely poor in 1999-2000 - an astonishing decline of 10\% from just 6 years earlier. The 55th round of the NSS broke with the long established convention of estimating household spending on a uniform reporting period basis. Under this system, respondents recall their spending on all items over a period of thirty days. The 55th round instead introduced a mixed reporting period of weeks, months and years. This made sense for all sorts of reasons (greater accuracy of recall, most notably), but it undermined the GOI's efforts to track poverty trends on a consistent basis. Adjustments made to the 55th round data by Angus Deaton and J ean Drèze suggest that the rate of poverty reduction in the 1990s was probably no greater than the rate of poverty reduction in the 1980s. ${ }^{26}$ Others, notably Abhijit Sen and Himanshu, have argued that the 1990s was a lost decade for poverty reduction. ${ }^{27}$

Why, then, "economic reform"? The usual answer is that the economic growth that led to poverty reduction in the 1980s was unsustainable. Huge subsidies into and out of the agricultural system (cheap fertilizer, water and power into and cheap food out of the Public Distribution System) ensured that India's growth spurt in the 1980s would push the country into the linked fiscal and balance of payments crises that erupted in 1991. Limited tax concessions to big business in the 1980s, combined with pervasive tax evasion, also forced both Congress and National Front (1989-91) governments to raise revenues by deficit financing and by borrowing more at home and abroad. Worse, the underlying 
structures of the Indian economy remained as sclerotic and irrational as ever. India had some of the highest rates of effective protection anywhere in the world. These barriers encouraged Indian business to provide goods and services that were increasingly unwelcome at home and that no one else in the world would buy. Early proponents of reform wondered aloud why Indians at home were condemned to poor service and poor jobs at the hands of the Permit-License-Quota Raj while Indians abroad were acclaimed for their hard work and innovation.

By 1990 it was clear that some elements within India's business communities, led by the Confederation of Indian Industry (CII), as well as significant parts of the urban middle class, were fed up with forms of economic mismanagement that discouraged innovation and limited choice in the shops. They objected to the pro-farming agendas of the National Front government, and they resented Prime Minister V. P.Singh's attempts to reward his mainly rural, mainly "backward classes" support base by extending systems of reservation (for government and public sector jobs and places in educational institutions) upwards from the Scheduled Castes and Tribes to those designated as Other Backward Classes.

By this time, too, the battles won by the likes of Margaret Thatcher in the U.K. and Ronald Reagan in the U.S. were changing the landscapes of international economic thinking. The disintegration of the Soviet Union in 1991 also had profound effects in India. These were felt first in terms of a loss of export markets and foreign assistance. Later on they helped push India closer to the U.S. and the World Trade Organisation. ${ }^{28}$ In the early-1990s the economist J ohn Williamson felt able to describe a new Washington Consensus on "sensible" macro-economic management. Development economics was already out of fashion by then. ${ }^{29}$ Deepak Lal had charged in 1983 that it was precisely a first generation of planners and development economists who had done the most damage in the "Third World." 30 These were the "guilty men" who had stalled economic progress in India by twenty years or more. Washington, for its part, used the debt crisis in Latin America to launch a broader assault on dirigiste forms of economic management. 
Developing countries needed to return to basics: to sound monetary and fiscal policies and to open trade and capital accounts. The elite revolt that led to Finance Minister Manmohan Singh's famous budget of 1991, and to the devaluation of the rupee that year by 18-20\% against leading currencies, was as much an echo of this thinking as it was a practical response to the balance of payments crisis that so damaged India's reputation for economic competency.

By the early summer of 1991, India's fiscal deficit stood at nearly 9\% of GDP and the country had sufficient foreign currency reserves to finance only two weeks worth of imports. Moody's and Standard and Poor had downgraded India's international credit rating. Finance Minister Manmohan Singh's budget was designed first and foremost to stabilize this situation. Cuts in defence spending and in subsidies for exports, sugar and fertilisers were meant to bring the fiscal deficit down to 6.5\% of GDP in the 1991-92 tax year. ${ }^{31}$ Thereafter, the government of Narasimha Rao moved steadily but not at any great pace to "adjust" the deeper structures of the economy. Efforts were made to liberalize India's trading regime, but even as late as 2000, despite considerable progress, tariffs in India still averaged close to 30\% and the ratio of international trade to GDP remained under 25\% (low by global standards). More progress was made with industrial policy. The system of industrial licensing that had taken shape since the 1950s was "dismantled in all but 18 designated industries (including drugs and pharmaceuticals, cars and sugar), and for all locations save for twenty-three cities with populations above one million people where licenses were still required for new ventures or project expansion."32 Perhaps most significantly of all, "the reforms," as they soon became known, opened the door to greater foreign direct investment in India's economy. Inward investment by Western multinationals became a major part of the new "Shining India" that was trumpeted by the Bharatiya J anata Party-led (BJ P) National Democratic Alliance ahead of the Lok Sabha elections in 2004. McDonalds in Delhi and Mumbai, along with IBM and Infosys in Bangalore, signalled India's connections to the new landscapes of globalization that had 
gathered pace in the 1990s, and which were strongly registered in the telecommunications revolution that swept through middle-class India.

No one now expects India to return to the dirigiste models that it pioneered half a century ago. Significantly, the Congress used the rise of the BJ P in the 1980s, and the destruction of the Babri Masjid in Ayodhya in December 1992, as a foil for its economic agenda. Leftist parties were warned that strong opposition to that agenda would cause the Rao government to fall, and that this in turn would bring the Hindu nationalists to power in New Delhi. ${ }^{33}$ As things worked out, the BJ P did come to power in India in 1998 and ruled the country until 2004. By then, however, the BJ $P$ had made its peace with globalisation and reform. It quietly retired its rhetoric of "swadeshi liberalisation" and its support for "microchips but not potato chips." By 2000 it was an enthusiastic advocate for a continuing process of economic liberalization that offered clear advantages to some of its supporters in the urban middle class.

Even the Communist Party of India (Marxist) (CPM) came to embrace liberalization. The CPM has continued to speak out against some aspects of the national reform agendas now being pressed by Prime Minister Manmohan Singh (from 2004). But in its West Bengal heartland it has embraced that agenda vigorously and with surprisingly little concern for its traditional support bases in the countryside and among government workers. In 2007, the public face of economic reform in India was focused for a while on Nandigram, a rural area in the Medinipur District of West Bengal. In March 2007, 14 people were killed in Nandigram after the ruling Left Front government in Kolkata instructed CPM cadres and the police to break resistance to their plans to expropriate 10,000 acres of local farming land. The land was earmarked for a Special Economic Zone (SEZ) to be developed by the Salim group of Indonesia. The Left Front government argued that a linked group of chemical works in Nandigram would create up to 100,000 jobs in West Bengal. They further noted that they had to do battle with eight other states to host a joint venture with the Salim group. 
The killings at Nandigram have taken on a significance that few in the Left Front government could have anticipated when contracts were signed. On the one hand, and most immediately, they advertised the willingness of the state in West Bengal to embrace what Marxists call "accumulation by dispossession." 34 In doing so they dramatized the violence of the accumulation process in other parts of India -along the Narmada river valley for example, where resistance to large dams continues, or wherever poor people are "tidied out" of street environments marked for improvement and upgrading (as they have been in many of India's leading cities, including through the grotesquely named Operation Sunshine in Kolkata). ${ }^{35}$ Development is never easy or painless, whatever the platitudes offered to the contrary by politicians or economic planners.

At the same time, Nandigram provides insight into changing geographies of power in India. Nehru found to his cost in the 1950s that he could not enforce land to the tiller reforms in the countryside, where power resided mainly with richer farmers. (Agricultural policy was handed to the states in the Constitution of India). Nevertheless, the federal settlement that was worked out between 1946 and 1949 placed India's states in a dependent relationship with the Center. ${ }^{36}$ President's Rule can be imposed on states under Article 356 of the constitution, and the inelasticity of major state revenues has forced them to seek extra funding from New Delhi in the form of grants-in-aid under Article 275.

In the 1990s, in contrast, and more so in the 2000s, many of India's states have been able to improve their bargaining position against the Center. RobJ enkins has argued that the reform process has empowered states to behave as "competition States." ${ }^{77}$ Instead of competing with one another to draw down funds from New Delhi, states like Maharashtra, Karnataka, Tamil Nadu or West Bengal now fight with one another to host foreign direct investments or the funds of Non-Resident Indians (NRIs). In J enkins' view, the real momentum of economic reform in India lies with the states. A process of "Provincial Darwinism" has taken hold, he argues, that compels states to compete with one 
another for the foreign funds that will reduce their fiscal deficits and dependence on New Delhi. Forcible evictions of peasants and harsher labor laws are just two instruments deployed by business-oriented elites to attract capital to their states. In some cases, too, and Nandigram illustrates this very well, states are being encouraged to free up extensive parcels of land as de facto fiefdoms of private capital: this, in effect, is the remit and purpose of the roughly 300 Special Economic Zones that were formed between 2005 and 2007 under the Act of that name.

\section{The Causes and Consequences of Uneven Growth}

The privatization of space is a necessary complement to the way the ongoing process of economic reform in India is being negotiated. To date, that process has been focused on the non-agricultural economy, and in towns and cities. There are sound political reasons for this, and it is widely agreed that successive governments in India since 1991 have managed the reform process with levels of determination and skill that evaded policy makers in the 1960s and 1970s. This in turn is causing observers of India to rethink their understandings of state-society relations. It is not simply that power is being leached from New Delhi to state capitals, important though this is. It is also becoming clear that a modernizing elite in India, pushed on no doubt by big business and the international community, but ably fronted by a band of far-sighted technocrats, first used the politics of crisis and now uses the politics of success to create a climate for ongoing reform that is nonetheless at odds still with market fundamentalism or the Washington Consensus. This is the real and considerable achievement of the CII and men like Manmohan Singh, Montek Singh Ahluwalia, and Palaniappan Chidambaram. If the reform agenda in India can be criticized for its partiality and unevenness, even for its slow speed, it can also be hailed as a success story that has avoided the pitfalls of the big bang approach to liberalization. ${ }^{38}$ A lot of progress has been made by stealth, and this has involved all 
manner of deals between different members of India's business and political elites. But the reform process in India has also been advanced by the careful building of coalitions, and by the bringing on side of politicians as well as "rent-seeking" elites in the states - those people, in other words, who had benefited most in the heyday of the Permit-License-Quote Raj and who might have been expected to slow it down. Significantly, too, the ongoing process of economic reform in India has led to a sharpening of the technical competency of some leading departments of government. Arguably, that competency was not there in the 1950s or 1960s to support the Nehru-Mahalanobis model of development.

The net effect of the reforms has been to widen the gulf between rich and poor people in India, and between rich and poor regions, but that was always going to be the case. The strongest arguments in the pro-reform locker are these: (a) that rates of average per capita income growth in India have been rising since 2003-04 beyond the 3.5\%-4.0\% levels recorded in the 1980s and 1990s; and (b) that such rates of grouth would not have been recorded without economic reform. Put another way, low levels of economic growth are no friend of the poor, nor are forms of economic management based on populist politics and deficit financing. In the short run, this argument has it, economic grouth must promote higher levels of income inequality —not that Indian levels are yet on a par with those of Brazil or China. Richer people will pull ahead as the economy rewards talent and scarce skills, as for example in the IT sector.

Meanwhile, the gap between the western and eastern states in India is opening up not because the latter are getting poorer, but because the former are getting richer. Again, we are seeing talent, or good economic policies, being rewarded. By the same token, poor people in Bihar are the victims of more than two decades of economic mismanagement. Laloo Prasad Yadav built a political coalition that rewarded Yadavs and Kurmis with dignity (izzat), and Muslims with protection, no mean feats both, but what he did not promote was a politics of development aimed at tightening labor markets (and thus raising real wages) or attracting inward investment. Per capita net state domestic product at 
constant 1993-94 prices actually fell in Bihar from Rs. 4,474 in 1990-01 to Rs. 3,396 in 2003-04 (in part because of the loss of J harkhand), while the residents of Uttar Pradesh, including the richer western parts of that state (but not Uttaranchal), saw their real incomes rise from Rs. 5,342 in 1990-91 to a still meager Rs. 5,975 in 2003-04. In the western state of Maharashtra, meanwhile, the corresponding figures show more than a sixty percent increase in real terms over thirteen years, from Rs. 10,159 and Rs 16,765. In Gujarat, the rate of economic expansion was even greater, with a per capita net state domestic product of Rs. 8,788 nearly doubling in 2004-05 to Rs. 16,878. 39

What is now evident in India, even more so than previously, is a yawning gulf between the country's haves and have-nots. For the former, India is shining brightly. It is a land of Tata Nanos and shopping malls. It is a country that seems to be leap-frogging the industrial revolution to land talented people directly in those jobs-in IT, information processing and finance - that connect India to the globalizing world outside. This is precisely the land of SEZs, the Golden Quadrilateral, Gurgaon, the Bandra Kurla complex in Mumbai, and various technopoles in Bangalore, Chennai and Hyderabad. Henri Lefebvre reminds us that capitalism advances "by occupying space, by producing [abstract] space," or by sweeping away those legal, cultural or political forces which conspire to slow down the circulation time of capital. 40 This is what we are beginning to see in India: the building of new urban and regional geographies that trumpet the country's modernity. Boosters of reform argue, furthermore, that the benefits of higher average rates of growth must in time trickle down to the poor. After a decade (the 1990s) when the rate of poverty reduction in India seemed to slow down, there are signs now that economic growth is again driving considerable reductions in the head count incidence of absolute poverty. Even in Bihar, changes appear to be under way, with Chief Minister Nitish Kumar advertising a business-friendly climate at some remove from the policies of his predecessor, Laloo Yadav. More tellingly, perhaps, the mushrooming growth of private, English-language schools in Bihar suggests an appetite on the part of some parents there to see their 
offspring join the circuits of economic growth and enrichment that are on offer elsewhere in India.

But here too is the rub. The anti-growth policies that have held back large parts of Bihar and Uttar Pradesh have more to do with state-level politics than with deliberate neglect on the part of New Delhi. If RobJ enkins is right, pressures will grow even in these two states, particularly among the middle-classes, for their ruling elites to embrace the reform agenda (as the CPM is doing in West Bengal). But there are also significant path dependencies at work here, a point sometimes lost on those urging Bihar to be more like Maharashtra. Aseema Sinha makes this point very well in her book on the regional roots of development politics in India. ${ }^{41}$ We need to recognise that India's recent experiments with high-tech growth depend in part on earlier (Nehruvian) rounds of investment in tertiary education (notably the Institutes of Technology and Management) and other forms of colonial and post-colonial support for private sector capitalist development in western India. In parts of eastern India, in contrast, slow growth may have been caused in large part by bad governance, but the governance systems in place there also reflect the continuing legacies of the Permanent Settlement and the more recent consequences of a Freight Equalisation Act that worked strongly to the disadvantage of states in India's resource triangle. Tim Besley and his colleagues note that the poverty-reducing effects of a given unit of GDP per capita growth in India are much less than in East Asia, where the distribution of landed wealth since circa 1950 has been much more even. Poverty elasticities in East Asia and the Pacific are greater than minus one (that is, $1 \%$ growth produces more than a $1 \%$ reduction in poverty), whereas in South Asia they are close to 0.6. But Besley and his collaborators also note that poverty elasticities in India vary from a high of - 1.23 in Kerala to a low of - 0.30 in Bihar. ${ }^{42}$ Even if economic growth does come to Bihar, their research suggests, the unevenness of land holdings, together with poor levels of existing infrastructure and primary education, will conspire to limit such povertyreducing effects as it might and should have. 
And here is a second difficulty. While it may be true that New Delhi has not set out to hold back Bihar since circa 1980 or 1991, the particular way in which India's urban and industrial elites have pushed forward the agenda of economic reform has done few favors for the eastern part of the country. To begin with, there is the matter of the agricultural economy. What is needed in Bihar, still, is agrarian reform, but this is not on the mainstream agenda. What we observe instead, as across India, is a crisis of profitability in agriculture. Young people are leaving the countryside in droves, driven out by poor rates of return on farming and pulled to the cities by the prospect of less onerous work. Close to $60 \%$ of Indians still find some employment in agriculture and allied sectors, but the share of the agricultural economy in India's GDP is now below $20 \%$. It will move down further over the coming decades. The countryside is also becoming the preserve of women, as more young men earn the major part of their livelihoods in the urban economy. More so than in the 1950s and 1960s, the cities of India really do represent the "modern" and there is every reason to suppose that an increase in education supply in the countryside will push young men (and some women) even faster to those places where they can wear Western clothes and hanker after office jobs. ${ }^{43}$

Whether decent jobs for high school or college graduates will be on offer is another matter. ${ }^{44}$ There are worries that India's reform trajectory is bringing with it jobless growth and the urbanization of poverty. It is sometimes forgotten that the IT sector accounts for only $2 \%$ of total services in India and only $1 \%$ of GDP (although it contributes around $5 \%$ of export earnings). ${ }^{45}$ That said, the manufacturing sector has been doing better than many critics have recognized, and there has been an enormous growth in employment since circa 1990 in the household industry sector. What is clear looking ahead is that the mass movement of people from rural to urban India has only just begun. We will see much more of it over the next twenty or thirty years, as the agricultural sector continues to shrink as a supplier of employment and as a contributor to GDP. When the GOI does finally turn its reforming spotlight on the countryside it will reduce the 
remaining subsidies that agriculture enjoys. It will also encourage the consolidation of larger farms, a process that is already under way in north-west India.

Finally, there is the matter of public goods provision, broadly defined. The most serious impediment to continued high rates of economic growth in India is the undersupply of infrastructure, from schools and hospitals to roads, railways and ports. The World Bank estimates that "India must invest around 3-4\% more of GDP on infrastructure to sustain growth of around 8\%, address existing gaps and meet policy-driven coverage goals." 46 This is a considerable sum of money to find in a country that is still returning significant fiscal deficits at both central and state levels (albeit that considerable progress has been made since circa 2004), and which still tolerates high levels of tax evasion. ${ }^{47}$ It is also not clear there is the political will yet in India to finance improvements in public sector health care and education provision. The preference is for people to pay for such goods in the private sector, an elite-driven policy choice that can be hugely damaging for poorer families.

Much less widely recognized outside India, although it has been referred to with some regularity by Prime Minister Manmohan Singh, is the worsening security situation in large swathes of eastern India, particularly in the so-called tribal belt. The retreat of functioning local government in parts of more than one hundred and fifty of India's 602 Districts has opened the door to a Naxalite movement that does on occasions seek to provide both security and basic goods for disadvantaged local people. It is unlikely that the Indian state will lose control of these territories in the same manner that the Government of Nepal lost almost all of the hill areas outside Kathmandu from 1996-2006. But any attempt to win back these blocks and districts will take time, and could well be bloody. In the meantime, they are no-go areas for economic development. Private investment will not flow to regions lacking clear property rights or an established rule of law. For better or worse, these Red Zones promise to be a significant brake on the production of abstract space - that is, functioning spaces for capital and modernization - in large parts of Bihar, 
Orissa, J harkhand, Chhattisgarh and Andhra Pradesh, not to mention in some of the north-eastern states.

\section{Conclusion}

The transformation of the Indian economy since 1980 has surprised most observers and deserves a positive press. The Indian economy will be the third largest economy in the world sometime in the mid-2030s (trailing only the USA and China). It is already in third place once adjustments are made for purchasing power parities (PPPs). Nominal average per capita incomes in India were just over $\$ 1,050$ in 2007, rising to $\$ 4,550$ in PPP terms: still placing India in the World Bank's band of Low Income Countries, but edging it closer to Middle Income status. Moving forwards, Rodrik and Subramanian note that, "Over a 40-year period, a 5.3 percent [per capita] growth rate would increase the income of the average person nearly 8-fold." 48 There are reasons to believe that India is now hitting a target rate of growth of GDP of 7\%, and that such growth rates can be continued at least up to 2025 (if not to 2040 or 2045 , by which time some decline in the rate of growth is to be expected, as capital-output ratios increase). The incidence of absolute poverty, measured by income, should fall sharply in the wake of high growth and will likely induce improvements in other measures of poverty and deprivation, including in respect of sanitation, child health and gender equality. These are all areas where India is behind its Millenium Development Goal (MDG) targets.

But nothing is guaranteed. India is still less dependent on world market conditions than many other emergent developing countries, but that dependence is set to grow. India is not immune to global crises, whether stock market crashes, rising energy prices or adverse climate change. Internally, the GOI has major political issues to negotiate in future, not just with regard to forms of cultural nationalism, including a possible backlash against "Westernization," but also in regard to gender issues (the role of women in the 
workforce, most notably) and the management of urban poverty or the containment of urban unrest. As things stand, all leading political parties in India support the agenda of economic reform. There is a growing sense that India's reform agenda is being driven by a culture of success, rather than by the politics of fear or necessity. The fruits of that initial success have gone overwhelmingly to India's elites and its urban middle classes, and upper castes, as was always bound to be the case. The challenge now, however, is for India to move on from a reform agenda inspired by elites in revolt against the Permit - LicenseQuota Raj. Opportunities need to be provided for poor and excluded people to participate in the new circuits of growth, not least if they are to be deterred in some regions from the paths of unrest, rebellion and/ or secession.

The political enfranchisement of India's poorest groups might still be the country's long-term salvation, much as Nehru once imagined. It is equally possible, however, that the politics of exclusionary growth will be reinforced. As yet, rapid economic grouth does not seem to be binding rich and poor Indians closer together. The privatization of space in India's cities surely hints at another future as well: that of the Latin America city, with all its glitz, crime, segregation and violence. Whichever way it goes, the future for economic development and social change in India is intimately bound up with its cities, and with the politics of urban management. Of that we can be certain. 


\section{Notes}

${ }^{1}$ Dani Rodrik and Arvind Subramanian, "Why India Can Grow at 7 Percent a Year or More: Projections and Reflections," IMF Working Paper/ 04/ 118 2004, p.6.

2 Gurcharan Das, India Unbound: The Social and Economic Revolution from Independence to the Global Information Age (New York: Anchor, 2002).

3 Kalpana Kochar, et al., “India's Pattern of Development: What Happened, What Follows," International Monetary Fund, Working Paper WP/06.02 www.imf.org/ external/pubs/ft/wp/ 2006/wp0622.pdf. 2006; see also Abhijit Banerjee, "The paradox of Indian growth: A Comment on Kochar et al." (Mimeo: MIT, available at www.mit.edu/faculty/download_pdf.php?id+1340). 2006.

4 After writing a first draft of this essay I was able to read Arvind Panagariya's spirited and upbeat account of India: The Emerging Giant (Oxford: Oxford University Press, 2008). Panagariya accepts that India's growth rate stepped up in the 1980s (to 4.8\% per annum 1981-88), but argues that the growth rate stepped up again - to 6.3\% - from 1988. Given that the run of annual GDP growth rates from $1987-88$ to $1993-94$ are $3.8 \%, 10.5 \%, 6.7 \%$, 5.6\%, 1.3\%, 5.1\% and 5.9\%, I find the cut-off date of 1988 (or 88-89: the year of $10.5 \%$ growth) unconvincing, if not indeed rather arbitrary.

5 Simon Kuznets, Modern Economic Growth: Rate, Structure and Speed (New Haven: Yale University Press, 1966).

${ }^{6}$ World Bank, India: Inclusive Growth and Service Delivery - Building on India's Success (Development Policy Review, Report No. 34580-IN) (Washington, DC: The World Bank 2006), Figure 1.12 and text. 
7 Stuart Corbridge and J ohn Harriss, Reinventing India: Liberalization, Hindu Nationalism and Popular Democracy (Cambridge: Polity Press, 2000).

8 Alan Heston, “National Income," in Dharma Kumar and Meghnad Desai (eds), Cambridge Economic History of India, Volume II, pp. 376-462 (Cambridge: University Press, 1982).

9 André Béteille, Caste, Class and Power: Changing Patterns of Stratification in a Tanjore Village (Berkeley: University of California Press, 1965).

${ }^{10}$ Quoted in Sunil Khilnani, The Idea of India (London: Hamish Hamilton, 1997), p. 35. ${ }^{11}$ See the chapter by J an Breman in this volume.

12 Hans Singer, "The Distribution of Gains Between Investing and Borrowing Countries," American Economic Review 40 (1950): 478-96; and Raoul Prebisch, The Economic Development of Latin America and Its Principal Problems (Lake Success, NY: United Nations, 1950).

13 Dadabhai Naoroji anticipated this argument in his Poverty and Un-British Rule in India (London: Swan Sonnenschein, 1901).

14 Ronald Inden, "Embodying God: From Imperial Progresses to National Progress in India," Economy and Society 24 (1995): 245-78.

15 William Arthur Lewis, "Economic Development with Unlimited Supplies of Labour," The Manchester School 22 (1954): 139-91.

${ }^{16} \mathrm{~J} \mathrm{ohn} \mathrm{Harriss.} \mathrm{"Does} \mathrm{the} \mathrm{'depressor'} \mathrm{still} \mathrm{work?} \mathrm{Agrarian} \mathrm{Structure} \mathrm{and} \mathrm{Development} \mathrm{in}$ India: A Review of Evidence and Argument," J ournal of Peasant Studies 19 (1992): 189227.

${ }^{17}$ Michael Lipton, Why Poor People Stay Poor: A Study of Urban Bias in World Development (London: Temple Smith, 1977). Charan Singh's views permeate much of his writings, but see esp. India’s Economic Policy: The Gandhian Blueprint (New Delhi: Vikas, 
1978, ch. v and Economic Nightmare of India: It Cause and Cure (New Delhi: National), 1981), chs, vi-viii. Thanks to Paul Brass for this insight.

18 V. M. Dandekar and Nilkanth Rath, "Poverty in India: dimensions and trends", Economic and Political Weekly [EPW], Vol. VI, No. 1 (2 J anuary 1971), pp. 25-48 and 10646.

19 Lloyd Rudolph and Susanne Hoeber Rudolph, In Pursuit of Lakshmi: The Political Economy of the Indian State (Chicago: University of Chicago Press, 1987).

20 Atul Kohli. Democracy and Discontent: India’s Growing Crisis of Governability (Cambridge: University Press, 1990).

21 Partha Chatterjee, A Possible World: Essays in Political Criticism (New Delhi: Oxford University Press 1977); also his The Politics of the Governed: Reflections on Popular Politics in Most of the World (New York: Columbia University Press, 2004). Sudipta Kaviraj, "On the crisis of Political Institutions in India," Contributions to Indian Sociology 18 (1984): 223-43; also his, “On State, Society and Discourse in India," in J ames Manor (ed.), Rethinking Third World Politics (Harlow: Longman, 1991), pp.72-89.

22 Kaviraj, “Crisis of Political Institutions,” p. 227.

23 Francine Frankel, India’s Political Economy, 1947-1977: The Gradual Revolution (Princeton: University Press, 1978); Pranab Bardhan, The Political Economy of Development in India (Oxford: Blackwell, 1984); J agdish Bhagwati, India in Transition: Freeing the Economy (Oxford: Clarendon, 1993).

24 Bhagwati, India; Thirukodikaval Nilakanta Srinivasan, "Reform of industrial and trade policies," EPW, Vol. XXVI, No. 37 (14 September 1991), pp. 2143-45.

25 Atul Kohli, "Politics of Economic growth in India, 1980-2005, Parts I and II," EPW, Vol. XLI, No. 13 (1April 2006), pp. 1,251-59 and 14 (8 April 2006), pp. 1,361-70. 26 Angus Deaton, and J ean Drèze, "Poverty and Inequality in India: a Re-examination," EPW, Vol. XXXVII, No. 36 (7 September 2002), pp. 3,729-48. 
27 Abhijit Sen and Himanshu, "Poverty and Inequality in India-I," EPW, Vol. XxxIX, No. 38 (18 September 2004), pp. 4,247-63 and “Poverty and Inequality in India-II," No. 39, pp. 4,361-75.

28 Kohli, "Politics of Economic Growth," p. 1,362.

29 J ohn Williamson, “Democracy and the 'Washington Consensus,"” World Development 21(1993): 1329-36.

30 Deepak Lal, The Poverty of 'Development Economics,' (London: Institute of Economic Affairs, 1993.

31 Drawing on Corbridge and Harriss, Reinventing India, p. 152.

32 Corbridge and Harriss, Reinventing India, p. 153.

33 See Ashutosh Varshney, “Mass politics or Elite Politics? India’s Economic Reforms in Comparative Perspective," in J effrey Sachs, et al. (eds.), India in the Era of Economic Reforms (New Delhi: Oxford University Press, 1999), pp. 222-60.

34 David Harvey, The New Imperialism (Oxford: Clarendon Press, 2003).

35 On Narmada, see Amita Baviskar, In the Belly of the River: Tribal Conflicts Over Development in the Narmada Valley (New Delhi: Oxford University Press, 1995). On Operation Sunshine, see Chatterjee, Politics of the Governed, p.61.

36 See Paul R. Brass, The Politics of India Since Independence , First edition (Cambridge: University Press, 1990).

37 Robert J enkins. "The developmental implications of federal political institutions in India," in Mark Robinson and Gordon White (eds.), The Democratic Developmental State (Oxford: University Press, 1998), pp. 187-214. See also Lawrence Sáez, Federalism Without a Centre: The Impact of Political and Economic Reforms on India's Federal System (Thousand Oaks: Sage, 2002).

38 See Bradford De Long, "India since Independence: an Analytical Growth Narrative," in Dani Rodrik (ed.), In Search of Prosperity: Analytic Narratives on Economic Growth 
(Princeton: University Press, 2003), p p 184-204. See also RobJ enkins, Democratic Politics and Economic Reform in India (Cambridge: University Press, 1999).

39 Government of India, Economic Survey, 2006-7 (New Delhi: GOI, Ministry of Finance, 2007), Table 10.4 .

40 Henri Lefebvre, The Survival of Capitalism (New York: St. Martin's Press, 1976), cited in David Harvey, Spaces of Capital, (Edinburgh: University Press, 2001), p. 376. ${ }^{41}$ Aseema Sinha, The Regional Roots of Development Politics in India: A Divided Leviathan (Bloomington: Indiana University Press, 2005).

42 Tim Besley, et al., Operationalising Pro-Poor Growth: A Country Case Study on India (Mimeo: Working Paper of Department of Economics, London School of Economics, www.lse.ac.uk/collections/LSEIndia/pdf/propoorgrowth.pdf, 2004), p.13.

${ }^{43}$ An important word of caution here. The feminization of the countryside in states like Haryana and Punjab is taking place in a context where child sex ratios indicate there are now less than 850 girls for every 1000 boys aged 0-6. Amartya Sen has argued that there are more than 100 million missing from the world today. Perhaps as many as 30 million of these women are missing from India; Amartya Kumar Sen, "More Than 100 Million Women Are Missing”, New York Review of Books, 20 December 1990.

44 See CraigJ effrey, Patricia J effery and Roger J effery, Degrees Without Freedom? Education, Masculinities and Unemployment in North India (Stanford: University Press, 2008).

45 Jim Gordon and Poonam Gupta, “Understanding India’s Services Revolution,” paper prepared for IMF-NCAER Conference (New Delhi, November 2003) www.imf.org/ external/np/apd/ seminars/2003/newdelhi/gordon.pdf. 46 World Bank, India, p.15.

47 See Barbara Harriss-White, India Working: Essays on Society and Economy (Cambridge: University Press, 2003). 
48 Rodrik and Subramanian, Why India Can Grow, p.6. 